\author{
Krzysztof Fiołek \\ http://orcid.org/0000-0002-6161-8563 \\ Uniwersytet Jagielloński \\ krzysztof.fiolek@uj.edu.pl \\ DOI: $10.35765 /$ pk.2020.2902.07
}

\title{
Stanisława Brzozowskiego wadzenie się z Polską: niepodległość poprzez nowoczesność
}

\section{STRESZCZENIE}

Artykuł poszukuje odpowiedzi na pytanie o psychologiczne konsekwencje i operacyjne korzyści afirmatywnej akceptacji nowoczesności przez Stanisława Brzozowskiego w kontekście jego sporu z tradycyjnie pojmowaną polskością. Brzozowskiego metoda odwołania się do pism polskiego romantyzmu (Filozofia romantyzmu polskiego) została zilustrowana na podstawie przykładów zaczerpniętych z publicystyki (Kultura $i$ życie), filozofii (Idee), powieści (Ptomienie, Sam wśód ludzi), a także wspomnień (Pamiętnik).

SŁOWA KLUCZE: niepodległość, Polska, modernizm, romantyzm, Stanisław Brzozowski

\section{ABSTRACT}

Stanisław Brzozowski’s Dispute with Polishness: Independence through Modernity

The paper explores the following question: what were the psychological consequences and operational benefits of the affirmative acceptance of modernity by Stanisław Brzozowski in the context of his dispute with traditional Polishness? Brzozowski's methods of reference towards Polish Romanticism writings (Filozofia romantyzmu polskiego) have been illustrated on the basis of the examples drawn from his journalistic (Kultura $i \dot{z y c i e}$ ), philosophical (Idee), novel (Ptomienie, Sam wśród ludzi), and reminiscent (Pamiętnik) texts.

KEYWORD S : independence, Poland, modernity, romantism, Stanisław Brzozowski

Stanisław Brzozowski umierał we Florencji już w 1911 roku, choć urodził się w tym samym roku co Leopold Staff, poeta trzech epok, żyjący 
do 1957 roku. Te najprostsze fakty biograficzne uzmysławiają obiektywne ograniczenie jego percepcji problematyki niepodległościowej do realiów porozbiorowych, a co za tym idzie - tragizm egzystencji przedwcześnie zakończonej. Odsunięty od krajowych emocji w końcowej fazie żywota, naznaczonej postępującą gruźlicą, autor Legendy Mtodej Polski nie doczekał tego ekscytującego momentu materializowania się idei niepodległościowej w trakcie Wielkiej Wojny i po jej zakończeniu. A może na swój sposób doczekał owej materializacji? Data zgonu w najprostszy sposób rozstrzyga sprawę, lecz można by się pokusić o przypuszczenie, że Brzozowski jednak doświadczył transferowania idei niepodległościowej z wyżyn abstrakcji i zakamarków konspiracji na twardy grunt krwawo tłumionych strajków robotniczych, zamieszek ulicznych, manifestacji patriotycznych. Nie doczekał niepodległości jako faktu z dziedziny prawa międzynarodowego, ale doczekał realnych przesłanek nabywania niepodległości innej, a w jego systemie aksjologicznym - ważniejszej. Albowiem związał ideę niepodległościową z programem emancypacji polskiego robotnika. W tak przyjętej optyce wydarzenia rewolucji 1905 roku były dla niego, zresztą podobnie jak chociażby dla Józefa Piłsudskiego, dowodem budzenia się odnowionego narodu. Oczywiście nigdy w takich momentach nie jest to cały naród, wszystkie jego stany czy klasy. Nie było tak ani w insurekcji kościuszkowskiej, ani w żadnym z dziewiętnastowiecznych zrywów niepodległościowych. Źródeł porażki tamtych rewolucji Brzozowski upatrywał w szkodliwej iluzji ogólnonarodowego kompromisu, która udaremniała szanse na każdą bardziej ofensywną strategię, jakiej wymagała od Polaków burzliwa chwila dziejowa. O szkodliwych zahamowaniach w łonie przywódczym polskich insurekcji jako czynniku wprost wiodącym do klęsk narodowych tak pisał w pamiętnym 1905 roku:

Jedność pomiędzy rewolucją a obawą przed nią jest logicznym nonsensem, przez historię jednak niejednokrotnie z krzywdą postępu urzeczywistnianym. Ten nonsens oddał w roku 1831 ster sił rewolucyjnych w ręce wodza, niewierzącego w te siły, co więcej - wrogiego rewolucji. W imię to jedności narodowej haniebnie zmarnowany został poryw listopadowy. Powtórzyło się to i w roku 1863. Jedność narodowa nakazywała u nas zawsze wchodzić w sojusze z targowicą i władzę jej oddawać. Proletariat polski pomyłek tego rodzaju nie popełni. Czynem objął on hegemonię społeczną na cały czas walki o prawa polityczne i wypuścić z rąk jej nie może. Kto czuje dziś identycznie z proletariatem polskim, ten czuje narodowo. Wszyscy inni bowiem pragną życia narodowego z zastrzeżeniami. Pragną życia narodowego o tyle tylko, o ile zgadza się ono z ich klasowymi interesami (Brzozowski, 2011, s. 80-81). 
Wydarzenia rewolucji 1905 roku nazywa Brzozowski pierwszym świadomym wejściem polskiego robotnika na arenę dziejów. W tym rozbudzeniu miejskiego proletariatu widział właściwie jedyną nadzieję na polską niepodległość, podobnie jak radykałowie Wielkiej Emigracji szans odzyskania państwowości upatrywali w politycznym przebudzeniu ludu polskiego. Dowartościowanie filozoficznego dorobku Wielkiej Emigracji jest wielce charakterystycznym rysem na mapie aksjologicznych wyborów Brzozowskiego. W nieszablonowej rozprawie Filozofia romantyzmu polskiego - zadedykowanej pamięci Stanisława Szczepanowskiego, który zasłynął jako surowy z pozycji romantycznych sędzia prądów modernistycznych $^{1}$ - rozszerza znaczenie filozofii, zbliżając ku takim pojęciom jak samowiedza i światopogląd:

Romantyzm polski filozofię swą posiada, gdyż jest wypływem - w części bezwiednym, w części, w ostatnim i szczytowym swym okresie, pełną samowiedzę swą posiadającym - jednolitego i określonego w zasadniczych przynajmniej swych rysach światopoglądu (Brzozowski, 1973, s. 375$)$.

W toku dalszych wywodów z Filozofii romantyzmu polskiego wyłania się zasadniczy priorytet antropocentrycznej predylekcji Brzozowskiego. Konfrontując romantyzm polski z filozofią niemiecką, wskazuje na zupełnie centralne dla swojej antropologii pojęcie swobody („władza nad sobą, od nikogo i niczego innego niezawisła, stwierdzona czynem”). Z szybkiego przeglądu stanowisk filozofów niemieckich wynika, że jedynie Fichte był gotów przyznać człowiekowi autonomiczne prawo bezwzględnej swobody. Natomiast inni (Kant, Hegel, Marks) uzależniają ową fundamentalną swobodę od rozmaitych czynników zewnętrznych (Kantowski noumen, Heglowski rozum powszechny, Marksowskie warunki ekonomiczne) (Brzozowski, 1973, s. 405). Rozwinięcie tej specyficznej

1 Kontrowersja wokół Dezynfekcji prądów europejskich (napaści na Zolę tudziė̇ wielbicieli nowych francuskich prądów artystycznych) jest szczegółowo omawiana niemal w każdym tekście dotyczącym „ukonstytuowania się” Młodej Polski. Atak na młode pokolenie polskich twórców, zafascynowanych - jak Tadeusz Konczyński - raczej Gabrielem D’Annunzio aniżeli Mickiewiczem, prowadził Szczepanowski właśnie z mandatu wielbiciela polskiej literatury romantycznej, strażnika narodowych hierarchii z przewodnią rolą wieszczów naszego romantyzmu. Zadedykowanie właśnie Szczepanowskiemu (zmarł w 1901 roku) Filozofii romantyzmu polskiego jest dowodem na całkowicie odrębne usytuowanie Brzozowskiego na mapie młodopolskich programów i dyskusji literackich. Warto przypomnieć, że w tym samym czasie, kiedy postanowił uhonorować Szczepanowskiego, zajmując się wieszczami, mesjanistami i towiańczykami, namiętnie dyskredytował bożyszcze Młodej Polski - Zenona „Miriama” Przesmyckiego. Wydaje się, że jedynym sensownym wyjaśnieniem tych reorientacji znowu muszą się stać niuanse stanowiska filozoficznego, wykuwająca się właśnie wówczas filozofia pracy. 
filozofii wolności (akurat tego określenia nieczęsto używano w odniesieniu do pomysłów Brzozowskiego) znalazło się w wykładach z października i listopada 1906 roku i celnie nazwane zostało światopoglądem pracy i swobody (Brzozowski, 1973, s. 415-485).

Filozofia romantyzmu polskiego jest przeważnie apologią wysiłku myślowego Cieszkowskiego, Hoene-Wrońskiego, Towiańskiego, Mickiewicza $\mathrm{i}$ innych. Bezkompromisowy oskarżyciel wszelkich marzycielskich uroszczeń duszy polskiej tutaj bierze w obronę radykalny gest filozofii narodo$w^{2}{ }^{2}$. Nie można mieć wątpliwości, że namysł nad mesjanizmem polistopadowym jest dla autora Idei czynnikiem wywołującym pytania i tezy jak najbardziej współczesne, młodopolskie rodem z Wyspiańskiego:

My bowiem nieustannie rozstrzygać mamy, czym ma być Polska i jakie są drogi, które do niej prowadzą. By zaś na te pytania odpowiadać, trzeba już mieć w sobie tę Polskę odrodzoną, trzeba dorobić się jej zasługą przebudowania wewnętrznego. Sprawę Słowa czynić może tylko ten, kto wie, w czym żyje Słowo, a aby to wiedzieć, trzeba to mieć w sobie. Mamy walczyć o kulturę i przyszłość Polski, przyszłość i tę kulturę stwarzać, a czyż powiedzieć o sobie możemy, że wiemy, czym ta przyszłość być ma, że mamy w sobie ducha tej przyszłej Polski? Tej Polski, jakiej chcemy, aby była? Sprawę prawdy może czynić tylko ten, kto ma ją w sobie. Sprawę Polski ten tylko, w kim ona żyje (Brzozowski, 1973, s. 409).

Z powodu książki Gloryfikacja pracy za pierwszego monografistę Brzozowskiego słusznie uchodzi... Marian Zdziechowski. Filozof i publicysta, profesor Uniwersytetu Wileńskiego, kojarzony z nurtem konserwatywnego pesymizmu dziejowego, w rozdziale trzecim wspomnianej monografii, zatytułowanym Walka z rzeczywistościa polska, akcentował bunt Brzozowskiego przeciw religii postępu (socjalizm) i dekadencji (prądy artystyczne zwane Młodą Polską). Zdziechowski wytknął Brzozowskiemu przesadne rozentuzjazmowanie się rewolucją 1905 roku i naiwny optymizm względem klasy robotniczej. Potem następuje eskalacja naturalnych uprzedzeń, gdy wyrzuca mu kryptoanarchizm rodem z filozofa anarchizmu, czyli... Hercena (Zdziechowski, 1916, s. 63-64). Brzozowskiego niewątpliwie pobudzała myśl o przyszłości wiązanej z ambitnie zaprojektowaną emancypacją proletariatu. Pozostał zwolennikiem Jutra, jak ów podróżny

2 W niedawnym artykule o idei mesjańskiej u Brzozowskiego Andrzej Wawrzynowicz pisze: „W filozofii romantyzmu naród polski dochodzi więc, zdaniem Brzozowskiego, do «ostatecznej samowiedzy» - uchwycenia fundamentów własnej tożsamości. Myśl romantyczna doprowadza do pełnej świadomości to, co wyłania się spoza empirycznej zmienności i przemijalności polskiej historii, a więc z samego następstwa pokoleń, jako pewna ponadczasowa forma - właściwy element jedności i niezmienności ducha polskiego” (2017, s. 76). 
z Widm moich wspótczesnych, przyglądający się konfrontacji pana Jutro i pana jaśnie wielmożnego (konsekwentnie pisany małą literą) (Brzozowski, 1914, s. 67-76). Był przekonany o potrzebie nieustannej transformacji, gdy pisał: „Pierwiastki postępowe naród tworzą, wsteczne - imienia jego wzywają nadaremno. To jest prawidło stałe” (Brzozowski, 1973b, s. 196). Szansą na niepodległość jest aktywne zawładnięcie siłami modernizacji przez ambitnych, dumnych i pracowitych Polaków. W niezwykle ostrym, wręcz napastliwym artykule zatytułowanym patetycznie Ludzkość $i$ naród tak prowokował ówczesnych czytelników:

Czy wy nie rozumiecie, że dzisiaj jedyną siłą jest wyrwać się z martwego objęcia historii? Polska historyczna upadła. Więc cóż: tak samo upadła historyczna Francja, Niemcy, Włochy. Kraje, gdzie najsilniej żyje historia, są najnieszczęśliwszymi krajami: mamy przecież Galicję, grobowiec szlacheckiej gangrenie na piersi konającego w nędzy i ciemnocie ludu postawiony - Kraków (Brzozowski, 1973b, s. 500).

Zatem recepta na chorobę bezwładnego tkwienia w objęciach historii jest jedna: intensywny trening emancypujących praktyk nowoczesności. Bo też zaraz obok likwidacyjnych niwelacji znajduje się swoiście patriotyczne credo Brzozowskiego:

Żyć u siebie tym, czym żyje ludzkość, energię, jaką wznieca upokorzona godność narodowa zwrócić na tworzenie u siebie kuźnic nowoczesności, zużyć patriotyczny żar na tworzenie nowoczesnego człowieka w Polsce. To jest tylko jedyna droga (Brzozowski, 1973b, s. 499).

W toku wydarzeń rewolucji 1905 roku radykalizują się przekonania polityczne wciąż jeszcze młodego publicysty „Głosu”, słynącego już (po kampanii antysienkiewiczowskiej i antymiriamowskiej) z surowości i krańcowości sądu. Do szczególnego paroksyzmu dochodzi awersja względem narodowych demokratów, którzy wobec proletariackiego zrywu przyjęli postawę jawnie niechętną. W drukowanych poza warszawską cenzurą artykułach (Odbywa się osobliwy sad...) Brzozowski z pasją dyskredytuje Stronnictwo Narodowo-Demokratyczne, w zasadzie odmawiając mu patriotyzmu poprzez sugestię, jakoby najtajniej skrywanym marzeniem endecji było połączenie tradycjonalistycznego frazesu patriotycznego $\mathrm{z}$ reakcyjną furią krwawej rozprawy ze zrewoltowanym proletariatem (Mencwel, 2014, s. 465-467). Andrzej Mencwel wskazywał, że nagły i sprawny kolportaż ulotek oskarżających Brzozowskiego o działalność agenturalną na rzecz ochrany był akcją odwetową podrażnionych koterii endeckich (Zygmunt Wasilewski i lwowskie „Słowo Polskie”) (Mencwel, 2014, s. 468). 
Koncepcja proletariackiej przyszłości odrodzonej Polski nie wzięła się u Brzozowskiego z przekonania o jakoby nieuchronnie nadchodzącej dyktaturze proletariackiej. Wydaje się raczej wynikiem radykalnie krytycznej refleksji o Rzeczypospolitej szlacheckiej i porozbiorowym resentymencie inteligencji polskiej. Oskarżenia rzucane w stronę szlachetczyzny i ziemiaństwa miały przygotować ideowy grunt pod wielki projekt kulturowej i moralnej przemiany narodu. W liście do Salomei Perlmutter czytamy jakże gorzkie tezy: „Renesans był zabawą zapustną. Reformacja iluzją samodzielności w szlachcie. Wiek XVII rozbija ucztę szlachty” (Brzozowski, 1970, s. 336).

Negatywizm w stosunku do narodowych tematów ustępował niekiedy bardziej zrównoważonej refleksji nad dominantą polskich dziejów. W toku swych przemyśleń wprowadził Brzozowski do tejże refleksji wiele nowoczesnych kategorii opisu i interpretacji historii. Wystarczy wspomnieć pojęcie typu ideogenetycznego (wzorca kultury) i próbę nakreślenia fenomenologii kultury szlacheckiej.

Michał Kaniowski był jedną z figur oskarżycielskich Brzozowskiego, jednym ze świadków w pozwie przeciw tradycji szlacheckiej. Dawna Polska jawi się Kaniowskiemu jako rzeczywistość bliska i realna, a jednocześnie fantasmagoryczna, stanowiąca represyjną domenę błędu, zalążkową postać współczesnych upokorzeń. Natenczas stłamszenie polskiego bytu narodowego prowadzić musi do „odrywania się jednostek samoistniejszych od narodowej wspólności” (Brzozowski, 2001, s. 443), czego Kaniowski miał być prowokacyjną egzemplifikacją.

Oczywiście takie fragmenty mogą być z powodzeniem brane jako przyczynek do autobiografii intelektualnej samego Brzozowskiego (Mencwel, 1976, s. 60), choć Kaniowski nie jest prostą figurą autora, a jedynie postacią wyposażoną w niektóre jego cechy świadomościowe. Widoczne się staje, że w umysłowości Brzozowskiego sposób istnienia historii łączył się z zagadnieniami dotyczącymi samego człowieka i jego uczestnictwa w stającym się świecie. „Nie było Polski, legend, wspomnień”, czyli nie było naonczas żadnego związku między kategoriami ściśle narodowymi a uniwersalnymi prawami „olbrzymiego świata”, jego istotą i przekształceniami, podobnie jak nie było kiedyś związku między polskością a „nowymi ideami” (zaświadczał o tym w Pamiętniku ${ }^{3}$. Historia Polski była zatem przez pewien czas w jego świadomości jak wyczerpana narracja, opowieść tkwiąca w ślepej uliczce istnienia akcji, epizod zamknięty;

3 „Dziś skarbem byłby dla mnie Szajnocha, Siemieński, Bartoszewicz, Bobrzyński, Baliński, wówczas nie umiałem z tego korzystać. Nie umiałem w tym okresie wyczuć żadnego związku między Polską a moimi nowymi ideami. Przeciwnie: idee odprowadzały mnie coraz dalej od polskości i postępy mierzyłem tą odległością" (Brzozowski, 2000, s. 62). 
wątek, do którego nie sposób już nawiązać, więc trudno poważnie traktować jego istnienie. Tego typu niechęć wobec specyficznie polskich zagadnień dochodzi do szczególnego paroksyzmu właśnie w powieści Ptomienie, ujawniając się w takich choćby dramatycznych pytaniach Kaniowskiego:

Polska, niepodległość - i cóż? Czy zmienisz się ty? (...) Czy życie ludzkie przestanie być tym, czym jest: potworną, cuchnącą niedorzecznością?... Czy nie tak samo rozpłynę się bez śladu, zginę na zawsze pod ciężarem mogilnej ziemi? Czy zmieni się cokolwiek bądź z tych rzeczy? (Brzozowski, 1996, s. 48).

Niniejszy szkic oczywiście nie rości sobie pretensji do przekrojowego rozpoznania całości zagadnienia, a jest jedynie próbą wskazania na oceny, tezy i wróżby na temat niepodległości Polski pojawiające się w różnogatunkowych wypowiedziach Brzozowskiego. Gdyby dociekać wszystkich przypadków jego ustosunkowania się do kwestii niepodległościowej, należałoby wziąć pod uwagę całą rozmaitość gatunków piśmiennictwa, których używał do zaprezentowania swoich myśli i emocji. Byłaby to zatem publicystyka wraz z krytyką literacką, eseistyka (studium O Maurycym Mochnackim), krytyka kultury (Legenda Mtodej Polski, Filozofia romantyzmu polskiego), powieściopisarstwo (Ptomienie, Sam wśród ludzi, Książa o starej kobiecie), a także listy (znane dzięki świetnemu opracowaniu Mieczysława Sroki) oraz niejednokrotnie wznawiany Pamiętnik. Jak widać, brakuje w tym wyliczeniu filozofii (Idee), gdyż ta raczej odciagała niż przyciągała do tematu polskości. Nie jest tu wyjątkiem Filozofia romantyzmu polskiego, którą należałoby traktować jako eseistyczne opracowanie tytułowego tematu aniżeli autonomiczną wypowiedź filozofa.

Obserwowany w ostatnim dziesięcioleciu kolejny renesans wzmożonego zainteresowania Brzozowskim, spowodowany konsekwentnymi akcjami wydawniczo-promocyjnymi „Krytyki Politycznej” ${ }^{4}$, a także licznymi rocznicowymi konferencjami naukowymi (Kowalczuk, Mencwel,

4 Niewątpliwą zasługą Wydawnictwa Krytyki Politycznej są wznowienia tekstów eseistycznych (Gtosy wśród nocy) i literackich (wydanie Ptomieni z ilustracjami Wilhelma Sasnala, książkowe wydanie zapomnianego dramatu Mocarz). Takie książki okazują się cennym uzupełnieniem dotychczasowych zasobów. Najambitniej zakrojoną inicjatywą pozostaje edycja Dziet Brzozowskiego, prowadzona od dziesięcioleci w krakowskim Wydawnictwie Literackim. Rok 2012 był dla tego przedsięwzięcia szczególnie udany: wydano sześć powieści Brzozowskiego w dwóch opasłych woluminach. Na stanowisku redaktora Dziet Andrzej Mencwel zastąpił Mieczysława Srokę, a opracowaniem tekstu zajął się Maciej Urbanowski, który następnie przygotował antologię Jest Bóg, żyje prawda. Inna twarz Stanistawa Brzozowskiego (Urbanowski, 2012). Kilka lat wcześniej w serii „Biblioteka Narodowa” wydawnictwa Ossolineum ukazał się Pamiętnik w opracowaniu Urbanowskiego, ze wstępem Marty Wyki (Brzozowski, 2008). 
Paczoska i Rodak, 2012), nie omijał zagadnień filozoficznych ${ }^{5}$. Jednak wyraźnie częściej komentowane były kwestie bliższe historii idei (tezy o nowoczesności, narodzie, katolicyzmie). Natomiast siła oddziaływania Brzozowskiego ma wyraźny związek z filozoficznym pogłębieniem jego publicystyki, eseistyki, krytyki literackiej, powieściopisarstwa i pamiętnikarstwa. Nawet jeśli wiele z sensów filozoficznych, wkomponowanych w rozmaite gatunki jego wypowiedzi, umykało w aktach recepcji. Filozoficzna podbudowa $z$ jednej strony i filozoficzny horyzont $z$ drugiej były i pozostały tą cechą pisarstwa Brzozowskiego, która jest wyzwaniem intelektualnym dla czytelnika, wzmagającym szacunek wobec autora. W dobie interdyscyplinarnych poszukiwań humanistycznych te właśnie pozaliterackie horyzonty stają się atutem Brzozowskiego, stawiając go po raz kolejny w gronie „naszych współczesnych”. Kolejne pokolenie literaturoznawców i kulturoznawców staje zadziwione wobec przenikliwości sądów autora Legendy Mtodej Polski, który w swym niedługim życiu niezwykle trafnie wskazał źródła i ujścia modernizmu, manowce „sztuki czystej”, perspektywy „społecznego ideału”. Był bez wątpienia człowiekiem swojej epoki, wspaniałym wykwitem pobudzenia intelektualnego społecznikowskiej lewicy warszawskiej początku wieku. Może dzięki wzniecaniu w czytelnikach oraz w sobie świadomości dziejowej mógł mocno odczuć ducha swoich czasów: kryzys wysokiego modernizmu, upadek kulturalnego prestiżu warstwy szlacheckiej, zarodki nowej kultury wspierającej się na barkach klasy pracującej ${ }^{6}$.

Temperament polemiczny nieustannie pchał go do ujęć stanowczych, kategorycznych, nie zawsze sprawiedliwych czy wyważonych. Do praktyk i idei uznanych za błędne czy szkodliwe odnosił się z wyraźnym gniewem, ich adwersarzy atakował z furią oskarżycielską, posługując się szyderstwem, satyryczną karykaturą. Wielokrotnie jednak dawał dostęp nieco innym uczuciom w stosunku do krytykowanych twórców i zjawisk. Gdy czytamy jego druzgocące tezy o Sienkiewiczu i Miriamie, nie czujemy w nich satysfakcji pamflecisty, lecz rozczarowanie czytelnika, smutek krytyka, szukającego wartości. Wszakże w takim tonie wypowiada się o całej Młodej Polsce jako niespełnionej obietnicy na niepodległość w kulturze. Zostaje zatem młodopolska legenda zamiast spełnienia, przeistoczenia idei wolą pracy w nieusuwalny fakt kulturalny, przemienienia słowa w ciało. Tymczasem Brzozowskiego, podobnie jak Wyspiańskiego, nie interesowała „Młoda Polska, o której szczebiocze kawiarnia”, lecz ta,

5 Serię nowych spojrzeń na autora Idei opublikował kilka lat temu kwartalnik „FA-art”. Najbardziej filozoficznym tropem idzie artykuł Pawła Tomczoka (2012, s. 72-83).

6 „Historię ludzie tworzą i oto jest moment, w którym zawiązują się pąki, dojrzewać mające stulecia” (Brzozowski, 2001, s. 55). 
która stawszy się ciałem, „walczy, aby posiąść ducha, aby siebie w całej swej niebywałej nowości, cudownym po raz pierwszy narodzeniu zrozumieć, utrwalić, posiąść" (Brzozowski, 2001, s. 55). W podobnym sensie niepodległość musi być stanowczym gestem woli kulturowego samostanowienia! Wszystkie atrybuty niepodległości będą już tylko konsekwencją tego fundamentalnego gestu.

Kłopot z Polską to boleśnie uwewnętrzniony przez Brzozowskiego dramat pokolenia, znaczony złamanymi życiorysami młodych Polaków. Miało się okazać, że było to ostatnie porozbiorowe pokolenie, gdyż jego wejście w społeczną dojrzałość dokonało się między 1900 a 1914 rokiem. Wiek XX przyniósł inne niedogodności dla tego i następnego pokolenia, niemniej jednak nie możemy zlekceważyć psychicznego zmęczenia i rozdrażnienia wprost wynikającego z przedłużającej się dziewiętnastowiecznej niewoli. Owo rozdrażnienie i dwubiegunowość sądów w kwestii niepodległości (od całkowitego pesymizmu do profetycznej pewności zwycięstwa) są wielce charakterystyczne dla całej spuścizny publicystycznej i literackiej Brzozowskiego. Wojciech Gruchała, komentując problematykę Ksiqżki o starej kobiecie, celnie uwypuklił jeden z sensów ostatniej, nieukończonej powieści Brzozowskiego - tłumienie idei niepodległościowej w sercach i na ulicach w odruchu samoobrony przed pokusą insurekcyjnego samobójstwa:

Czytelnik jest świadkiem walki matki ze światem o syna. Zagrożenie z zewnątrz przybiera postać idei mogącej uwieść młodzieńca i wplątać w wir historii, który od wieków pozbawia domy polskie ojców, synów, mężów. Trzeba więc zerwać ze słupa ulotkę nawołującą do odrodzenia niepodległego kraju, zasłonić okno, gdy carska policja aresztuje młodego lekarza kreślącego na murze buntownicze hasło (Gruchała, 2008, s. 72).

W toku późniejszej działalności artystyczno-filozoficznej Brzozowski wyrażał pochwałę wielkiego przeobrażenia świadomości polskiej, jakie dokonywało się w XIX wieku pod wpływem tendencji romantyczno-mesjańskiej i pozytywistyczno-socjalistycznej. Taki horyzont problemowy miał się wyłaniać z monumentalnie zakrojonej powieści Dębina. Gdyby została ukończona, mogłaby stanowić intelektualno-artystyczną kontrpropozycję wobec świata Sienkiewiczowej Trylogii.

W ferworze oskarżeń i replik, w kontekście „sprawy Brzozowskiego”, nie wahano się przecież widzieć w Brzozowskim renegata, choć później odczytywano w jego pismach patriotyzm $\mathrm{z}$ tradycji gorzkich napomnień, czyli zestawiano ze Skargą, Staszicem czy Mochnackim7. Do

7 Pierwszym, który zaszeregował Brzozowskiego w tej chwalebnej tradycji był Bronisław Chlebowski (1910, s. 55). Inni zazwyczaj zgadzali się z tak wyznaczonymi pokrewieństwami, por. Suchodolski, 1974, s. 103. 
Brzozowskiego można by odnieść jego własne słowa, które wypowiedział o młodym Adolfie Nowaczyńskim: „W nim tkwiło jako instynkt palące poczucie kłamstw naszej kultury” (Brzozowski, 2001, s. 218). W artykule Testament Cypriana Norwida zarzuca stronnictwu konserwatywnemu z Galicji, a także krakowskiej Akademii Umiejętności praktyczne zastosowanie hasła ,precz z Polską” (przypisywanego radykalnym socjalistom) z powodu polityki wydawniczej Akademii, wedle której bizantyńscy ojcowie Kościoła są przedkładani ponad opracowanie pism Wrońskiego, Słowackiego, Lelewela, Trentowskiego, Libelta, Kołłątaja (Brzozowski, 1973c, s. 217).

W swoich wspomnieniach Józef Czapski twierdził, że to Brzozowskiemu zawdzięcza swoje nawrócenie na polskość (Miłosz, 2000, s. 7). Pisze Czapski bardzo porywająco o swoim odkryciu Legendy Mtodej Polski, która wyzwolić go miała z kompleksów wobec kultury rosyjskiej (Czapski, 1983, s. 278-280). Wzruszającą skądinąd opowieść Czapskiego o przypadkowym natknięciu się w Krakowie w 1919 roku na egzemplarz Legendy Mtodej Polski przypomniała niedawno antologia Jest Bóg, żyje prawda:

Z pobytu wówczas w Krakowie nie zachowałem wspomnień ani Wawelu ani kopca Kościuszki ani Panny Marii, ale pamiętam dokładnie ciemny salonik-poczekalnię jakiegoś dentysty, gdzie na stole, pod brzydką secesyjną lampą, wśród brudnych, sto razy przeglądanych pism ilustrowanych odkryłem Legendę Młodej Polski. (...) Potem już, idąc w głąb tej książki, odkrywałem z upojeniem to, czego nigdy Rosja dać mi nie mogła, że droga moja do idei ludzkości, która mnie na Wschodzie urzekła, prowadzi przez Polskę, że jej rozwoju nie tylko nie muszę, ale nie mam prawa lekceważyć. Poprzez okrutny pamflet na Polskę zdziecinniałą, jedyną, jaką znałem dotychczas, odkrywałem inną Polskę. Mój kompleks niższości wobec wielkiej ojczyzny Tołstoja, Dostojewskiego i rewolucji przestał istnieć (Czapski, 2012, s. 305).

Jak wiadomo, sam Brzozowski również miał za sobą zauroczenie literaturą i myślą rosyjską od czasu młodzieńczych wtajemniczeń w pisma Michajłowskiego, Pisariewa, Czernyszewskiego, Bielińskiego. Tu znowu Brzozowski jawi się jako autor nieprzewidywalnych reakcji czytelniczych. Albowiem spuścizna Brzozowskiego to w znacznej części obszar wyborów, których każdorazowo dokonuje odbiorca podczas obcowania z dziełem. Wiele zależy wtedy od pytań, potrzeb i zahamowań, z jakimi podchodzi się do tych niepokornych książek, domagających się szczególnego rodzaju odpowiedzialności.

Dla Brzozowskiego zarówno zniewolenie, jak i niepodległość miały sens intelektualny, oznaczały stopień panowania nad rzeczywistością, zależność lub suwerenność w kulturze. Instytucjonalno-prawne potwierdzenie 
kompetencji i praw przyznanych sobie własnymi siłami było w takim przewartościowaniu całkowicie wtórne wobec aktu osobistego wybicia się na niepodległość.

Wiodącą skłonnością oraz wspólnym mianownikiem poszukiwań filozoficznych Brzozowskiego wydaje się antropocentryzm, który w różnych stężeniach i frazeologiach odnaleźć można w tak odległych propozycjach duchowych, jak przybyszewszczyzna, nietzscheanizm, filozofia czynu i pracy, personalistyczny modernizm katolicki. W próbach literackich ów antropocentryzm emanuje blaskiem aktywistycznego indywidualizmu licznych protagonistów: Konrad Czyński (Pod ciężarem Boga) - ksiądz wyzwalający się z ograniczeń tożsamości kapłańskiej; charyzmatyczny redaktor „Przyszłości” Antoni Walczak (Mocarz); prometejski radykał rewolucyjnej emancypacji Michał Kaniowski (Ptomienie); syn podbitego narodu Roman Ołucki, poskramiający uzurpacje intelektualne pruskiego apologety Trutha (Sam wsród ludzi). Spektakularnym finałem tych praktyk egzaminacyjnych dokonywanych na konstrukcjach literackich jest widoczny pod koniec życia zwrot ku paktowi autobiograficznemu: autoparodystyczna kreacja Teofila Łaguny (Ksiazika o starej kobiecie); umierający poeta-filozof (taki napis na florenckim nagrobku dostał ostatecznie Brzozowski), piszący testament adresowany do sumień przyszłych pokoleń (Pamiętnik).

Antropocentryzm Brzozowskiego jest dialektyczny, wynika z nieustannej konfrontacji niegotowego człowieka z ,gotowym bytem" oraz tym, co „pozaludzkie”. Antropocentryzm taki można też nazwać inkluzywnym, gdyż wobec zagrożenia ze strony „pozaludzkiego” optuje za angażowaniem się twórczej jednostki w struktury kolektywistyczne (wspólnota wolnych wytwórców). Poszukiwanie dziejowego oparcia dla człowieka stało się przy końcu życia jedną z przyczyn zafascynowania metodą utrwalania prawd wiary w formach instytucjonalnych, metodą praktykowaną od wieków przez Kościół katolicki. Antropocentryzm Brzozowskiego można też nazwać procesualnym. Myślenie w kategoriach trwającego procesu zabezpieczało przed uzurpacjami gotowych form i znieprawiającymi poszukiwaniami zewnętrznych źródeł siły. „Niewielu ludzi jest w stanie pogodzić się z myślą, że najrozumniej jest patrzeć na życie własne jak na proces, którego sens, jeżeli w ogóle istnieje, nie dotyczy jego uczestników" (Brzozowski, 1990, s. 361) - napisał w najdonioślejszym artykule filozoficznym ze zbioru Idee. Kolejne dziesięciolecia recepcji i interpretacji nakazują również na dziedzictwo intelektualne Brzozowskiego spoglądać jak na proces, którego sens od dawna istnieje daleko poza historycznym człowiekiem, będąc arcyludzkim świadectwem iście norwidowskiej pracy pokoleń nad pozostawionym testamentem filozoficzno-moralnym. Jednak ten szeroki horyzont człowieczeństwa nie unieważniał perspektywy ściśle polskiej: 
Trzeba myśleć, trzeba przekonywać siebie, trzeba przypominać, że Polska to także warunek nieupośledzonej przyszłości 20 milionów, które miały, mają lub będą miały nieszczęście urodzić się Polakami (Brzozowski, 2008, s. 22).

\section{BIBLIOGRAFIA}

Brzozowski, S. (1914). Widma moich wspótczesnych (Fikcyjne portrety satyryczne). Lwów: Księgarnia Polska Bernarda Połonieckiego.

Brzozowski, S. (1970). Listy. T. 1. Oprac. M. Sroka. Kraków: Wydawnictwo Literackie.

Brzozowski, S. (1973a). Filozofia romantyzmu polskiego. W: S. Brzozowski, Kultura $i$ zycie. Warszawa: Państwowy Instytut Wydawniczy, 375-414.

Brzozowski, S. (1973b). Kultura i zycie. Zagadnienia sztuki i twórczości. W walce o światopogląd. Warszawa: Państwowy Instytut Wydawniczy.

Brzozowski, S. (1973c). Testament Cypriana Norwida. W: S. Brzozowski, Kultura $i$ życie. Warszawa: Państwowy Instytut Wydawniczy, 217-224.

Brzozowski, S. (1990). Idee. Wstęp do filozofii dojrzatości dziejowej. Oprac. A. Walicki. Kraków: Wydawnictwo Literackie.

Brzozowski, S. (1996). Ptomienie. Z papierów po Michale Kaniowskim wydat $i$ przedmowa poprzedzit Stanistaw Brzozowski. Warszawa: Państwowy Instytut Wydawniczy.

Brzozowski, S. (2000). Pamiętnik. Fragmentami listów autora i objaśnieniami uzupełnił O. Ortwin. Warszawa: Czytelnik.

Brzozowski, S. (2001). Legenda Młodej Polski. Kraków: Wydawnictwo Literackie.

Brzozowski, S. (2008). Pamiętnik. Oprac. M. Urbanowski, wstęp M. Wyka. Wrocław: Ossolineum.

Brzozowski, S. (2011). Pisma polityczne. Warszawa: Wydawnictwo Krytyki Politycznej.

Chlebowski, B. (1910). Książka Brzozowskiego. Książka, 2, 49-55.

Czapski, J. (1996). O Stanisławie Brzozowskim. W: J. Czapski, Patrząc. Kraków: Znak, 305-323.

Czapski, J. (2012). O Brzozowskim. W: M. Urbanowski (oprac.), Jest Bóg, żyje prawda. Inna twarz Stanistawa Brzozowskiego. Warszawa: Wydawnictwo Fronda, 299-317.

Gruchała, W. (2008). Są solą ziemi. O „Książce o starej kobiecie” Brzozowskiego. Dekada Literacka, 4, 28-31.

Kowalczuk, U., Mencwel, A., Paczoska, E. i Rodak, P. (red.). Konstelacje Stanistawa Brzozowskiego. Warszawa: Narodowe Centrum Kultury \& Wydawnictwo Uniwersytetu Warszawskiego.

Mencwel, A. (1976). Stanistaw Brzozowski. Ksztattowanie mysli krytycznej. Warszawa: Czytelnik. 
Mencwel, A. (2014). Stanistaw Brzozowski. Postawa krytyczna. Wiek XX. Warszawa: Wydawnictwo Krytyki Politycznej.

Miłosz, C. (2000). Cztowiek wśród skorpionów. Studium o Stanistawie Brzozowskim. Kraków: Znak.

Suchodolski, B. (1974). Brzozowski dziś. W: A. Walicki i R. Zimand (red.), Wokót mysli Stanistawa Brzozowskiego. Kraków: Wydawnictwo Literackie, 99-126

Tomczok, P. (2012). Idea prawa Stanisława Brzozowskiego. FA-art, 1-2, 72-83.

Urbanowski, M. (2008). Jest Bóg, żyje prawda. Inna twarz Stanistawa Brzozowskiego. Warszawa: Wydawnictwo Fronda.

Wawrzynowicz, A. (2017). Epistemologiczny kontekst idei mesjanizmu polskiego w ujęciu Stanisława Brzozowskiego. Tekstualia, 3, s. 75-84.

Zdziechowski, M. (1916). Gloryfikacja pracy. Mysli z pism i o pismach Stanistawa Brzozowskiego. Petersburg: Drukarnia W. Lesmana.

Krzysztof Fiołek - pracuje w Katedrze Historii Literatury Pozytywizmu i Młodej Polski na Wydziale Polonistyki Uniwersytetu Jagiellońskiego. Autor książki Przetrwanie i przetwarzanie. Programy kultury narodowej w epoce Mtodej Polski (2010). Redaktor ksiąg zbiorowych: Kraków i Galicja wobec przemian cywilizacyjnych 1866-1914 (wspólnie z Marianem Stalą); Literatura niewyczerpana. W kręgu mniej znanych twórców polskiej literatury lat 1863-1914 (2014). Zajmuje się historią polskich sporów światopoglądowych, ich odbiciem w literaturze i publicystyce, a także przemianami społeczno-cywilizacyjnymi, ukazanymi w powieści galicyjskiej. 
